\title{
E-LITIGATION AS THE AMENITIES FOR THE PRINCIPLE OF CONTANTE JUSTITIE MANIFESTATION OF CIVIL JURISDICTION IN INDONESIA
}

\section{E-LITIGATION SEBAGAI SARANA MEWUJUDKAN ASAS CONTANTE JUSTITIE PADA PERADILAN PERDATA DI INDONESIA*}

\author{
Zil Aidi \\ Fakultas Hukum, Universitas Diponegoro \\ Jalan Prof. Soedarto, Tembalang, Semarang. \\ e-mail: zil.aidi93@gmail.com
}

\begin{abstract}
E-litigation or electronic-based trials is one of the features of e-court. This study seeks to provide answers regarding the extent to which the role of e-litigation in realizing the principle of contante justitie in the judiciary in Indonesia, especially in civil courts. This research also discusses what factors hinder the implementation of e-litigation in civil courts in Indonesia. The research that uses Yogyakarta District Court (PN) and Marabahan District Court (PN) as the object is qualitative research, which is juridical empirical and analyzes the collected data using qualitative descriptive methods.) The results showed that both the Yogyakarta District Court and the Marabahan District Court had e-litigation features available. Still, they had not fully contributed optimally in realizing the contante justitie principle in civil court. In the two PN's above, there are already several court users who use the e-litigation feature, especially regarding the submission of claims, answers, replicas, duplicates, conclusions, and written evidence electronically as reading the verdict electronically. However, for the electronic examination of witness and expert evidence, no court user has used it. The things that hinder the implementation of e-litigation in those district courts are court users' reluctance to use the e-litigation feature due to the unpractical regulation and the lack of internet availability signal access.
\end{abstract}

Keywords: Civil Procedural Law; E-Litigation; Contante Justitie Principle.

\begin{abstract}
Abstrak
E-litigation atau persidangan yang berbasis elektronik merupakan salah satu fitur dalam ecourt. Penelitian ini berupaya memberikan jawaban terkait sejauh mana peranan e-litigation dalam mewujudkan asas contante justitie pada peradilan di Indonesia, terkhususnya pada peradilan perdata. Penelitian ini juga membahas mengenai faktor apa yang menghambat terimplementasinya e-litigation pada peradilan perdata di Indonesia. Penelitian yang menjadikan Pengadilan Negeri $(P N)$ Yogyakarta dan Pengadilan Negeri (PN) Marabahan sebagai objek penelitian ini merupakan penelitian kualitatif yang bersifat yuridis empiris dan menganalisa data yang terkumpul dengan metode deskriptif kualitatif. Hasil penelitian menunjukan bahwasanya baik di PN Yogyakarta maupun PN Marabahan sebenarnya telah tersedia fitur e-litigation namun belum sepenuhnya dapat berkontribusi optimal dalam mewujudkan asas contante justitie pada peradilan perdata. Pada kedua PN di atas sudah terdapat beberapa pengguna peradilan yang menggunakan fitur e-litigation terkhusunya terkait penyampaian gugatan, jawaban, replik, duplik, kesimpulan serta alat bukti tertulis secara elektronik maupun pembacaan putusan secara elektronik, namun untuk pemeriksaan alat bukti saksi maupun ahli secara elektronik belum ada pengguna peradilan yang memanfaatkannya. Adapun hal yang menghambat terlaksananya e-litigation pada dua instansi pengadilan tersebut adalah disebabkan oleh masih adanya keengganan dari pengguna peradilan
\end{abstract}

\footnotetext{
* Naskah diterima: 13 November 2020, direvisi: 5 Maret 2021, disetujui untuk terbit: 25 Maret 2021

Doi: $10.3376 /$ jch.v6i2.310
} 
untuk menggunakan fitur e-litigation, kemudian dari regulasi e-litigation itu sendiri yang kurang praktis untuk digunakan oleh pengguna peradilan serta belum meratanya ketersediaan akses sinyal internet yang memadai pada PN di daerah.

Kata Kunci: Hukum Acara Perdata; E-Litigation; Asas Contante Justitie.

\section{PENDAHULUAN}

Indonesia adalah negara yang mentasbihkan diri sebagai negara hukum. Hal ini sebagaimana termaktub jelas dalam Pasal 1 ayat (3) Bab I Amandemen Ketiga Undang-Undang Dasar (UUD) Negara Republik Indonesia 1945. Konsekuensi logis dari Pasal 1 ayat (3) UUD 1945 tersebut adalah adanya suatu kewajiban bagi Indonesia untuk memastikan hadirnya suatu peradilan yang accessible, efektif, efisien serta berbiaya rendah.

Pengejawantahan dari hal tersebut dapat terlihat dalam Pasal 2 ayat (4) Undang-Undang No. 48 Tahun 2009 tentang Kekuasaan Kehakiman yang pada pokoknya menyatakan "Peradilan dilakukan dengan sederhana, cepat, dan biaya ringan". Peradilan yang dilakukan dengan sederhana, cepat dan biaya ringan sejatinya merupakan suatu asas yang dikenal sebagai asas contante justitie. Adapun maksud dari asas ini adalah proses peradilan yang tidak berbelit-belit, acaranya jelas, mudah dipahami, dan biaya yang terjangkau oleh masyarakat tingkat bawah sekalipun (Hairi, 2011).

Lembaga Penelitian, Pendidikan dan Penerangan Ekonomi dan Sosial (LP3ES) pada bulan Mei 2019 melakukan survei kepuasan publik terhadap lembaga pengadilan. Survei tersebut menunjukkan hasil bahwa indeks kepuasan publik terhadap lembaga peradilan berada pada kategori baik, yakni sebesar 76\%. Hal tersebut mengindikasikan peningkatan sebesar $6.7 \%$ bila dibandingkan dengan indeks kepuasan yang ada pada tahun 2013 (Susthira, 2019). Meskipun sudah relatif baik namun Mahkamah Agung selaku stakeholder utama masih memiliki pekerjaan rumah terutama terkait dengan aspek layanan administrasi dan persidangan yang masih membutuhkan terobosan guna meningkatkan pelayanannya kepada segenap pengguna peradilan.

Meskipun secara praktis di Indonesia terdapat pengaturan agar proses berperkara di pengadilan dapat berjalan dengan sederhana, cepat dan biaya ringan, dalam kenyataannya tidak sepenuhnya dapat dilaksanakan, khususnya dalam perkara-perkara perdata, bahkan biaya yang harus dikeluarkan para pihak justru tidak sedikit (Basarah, 2007). Berdasarkan Laporan Pelaksanaan Kegiatan yang diterbitkan oleh Mahkamah Agung, terdapat 48.856 perkara perdata pada Pengadilan Negeri. Akan tetapi, perkara yang diputus pada tahun 2019 hanya sebesar 35.323 perkara, sehingga masih terdapat sisa perkara sebesar 13.533 perkara (Mahkamah Agung, 2019b). Apabila penyelesaian perkara menjadi lambat berarti keadilan menjadi tertunda dan berakibat menurunnya kewibawaan pengadilan. Hal ini berdampak negatif terhadap 
perkembangan dan pembangunan hukum melalui pengadilan (Suparman, 2019).

Berangkat dari kondisi itulah e-court atau peradilan berbasis elektronik hadir sebagai suatu terobosan Mahkamah Agung guna memperbaiki pelayanan administasi dan persidangan. E-Court adalah sebuah instrumen pengadilan sebagai bentuk pelayanan terhadap masyarakat dalam hal pendaftaran perkara secara online (e-filing), taksiran panjar biaya secara elektronik (e-SKUM), pembayaran panjar biaya secara online (epayment), pemanggilan pihak secara online (e-summons) dan persidangan secara online (e-litigation) (Mahkamah Agung, 2019). Melalui e-court, dapat mempermudah proses administrasi pengadilan dimana para pihak dapat melakukan pendaftaran perkara secara online menggunakan sistem tersebut. Selain mempermudah proses administrasi pengadilan, keberadaan e-court ini tentu sejalan dengan adanya revolusi industri yang menuntut kinerja yang berbasis teknologi (Sari, 2019).

E-court diluncurkan pada tahun 2018 dengan terbitnya Peraturan Mahkamah Agung (PERMA) Nomor 3 Tahun 2018 tentang Administrasi Perkara di Pengadilan Secara Elektronik. Selanjutnya, pada bulan Agustus 2019 Mahkamah Agung menerbitkan Peraturan Mahkamah Agung (PERMA) Nomor 1 Tahun 2019 tentang Administrasi Perkara dan Persidangan di Pengadilan Secara Elektronik sebagai bentuk penyempurnaan dari e-court. Adapun salah satu perbedaan mendasar yang terdapat pada PERMA Nomor 1 Tahun 2019 dan tidak dapat ditemukan pada PERMA Nomor 3 Tahun 2018 adalah keberadaan fitur e-litigation atau persidangan secara elektronik.

Berdasarkan pembahasan di atas maka penting untuk diteliti apakah aspekaspek pada fitur e-litigation di atas telah dapat terimplementasi dengan baik dan berperan dalam mewujudkan asas contante justitie pada peradilan perdata di Indonesia. Lebih lanjut, juga penting untuk diketahui hambatan apa saja yang sekiranya menghalangi penerapan elitigation pada peradilan perdata di Indonesia untuk kemudian dapat dirumuskan solusi guna kemajuan praktik e-litigation di Indonesia.

Pembahasan mengenai hal ini menjadi urgent untuk dikaji mengingat Pada bulan September 2019 lalu, Ketua Mahkamah Agung Republik Indonesia, Hatta Ali telah menargetkan bahwasanya per tahun 2020 e-litigation sudah diterapkan di seluruh pengadilan tingkat pertama di Indonesia (Andayani, 2019).

Dalam perspektif yang berbeda, penerapan e-litigation menjadi kian penting untuk dibahas karena media Maret 2020 hingga saat ini Indonesia tengah mengalami pandemi virus COVID-19. Pengadilan tidak dimungkinkan untuk mengadakan persidangan sesuai dengan standar yang telah diatur sebelumnya, karena dapat menimbulkan kerumunan orang, yang menyebabkan risiko penyebaran virus COVID-19 semakin tinggi (Lumbanraja, 2020). Adanya e-litigation yang 
Zil Aidi: E-Litigation Sebagai Sarana Mewujudkan Asas Contante Justitie Pada Peradilan...

menggunakan video atau web conference dapat menjadi sarana yang efektif guna menggelar sidang oleh Pengadilan Negeri, Kejaksaan, atau Rumah Tahanan (Anggraeni, 2020).

Berdasarkan latar belakang di atas menarik untuk diteliti dan dikaji mengenai, bagaimana peran e-litigation dalam mewujudkan asas contante justitie pada peradilan perdata di Indonesia dan apa saja faktor yang menghambat terimplementasinya e-litigation pada peradilan perdata di Indonesia.

\section{METODE PENELITIAN}

Penelitian pada hakikatnya adalah suatu kegiatan yang mencari kebenaran dari suatu ilmu pengetahuan, dimana penelitian itu lahir dari adanya keraguan atau keingintahuan terhadap suatu masalah (Asikin, 2004)

Dalam tulisan ini penelitian yang dilakukan merupakan penelitian yuridis empiris. Pendekatan yuridis empiris adalah pendekatan yang melihat suatu kenyataan hukum di dalam masyarakat yang bagaimana peran e-litigation dalam mewujudkan asas contante justitie pada peradilan perdata di Indonesia dan apa saja faktor yang menghambat terimplementasinya e-litigation pada peradilan perdata di Indonesia.

Selanjutnya, untuk mengetahui hal ini maka akan digunakan analisis data yang bersifat kualitatif. Data kualitatif dalam hal ini berupa kata-kata, sehingga laporan penelitian akan berisi kutipan-kutipan data untuk memberi gambaran penyajian yang berasal dari wawancara dan beberapa catatan lapangan.

\section{HASIL DAN PEMBAHASAN}

\section{Asas Contante Justitie dan Kebijakan Investasi}

Periode pertama pemerintahan Presiden Joko Widodo tahun 2014-2019 berfokus pada penguatan dan pertumbuhan ekonomi dimana hal ini terlihat pada diterbitkannya 16 Paket Kebijakan Ekonomi (PEK) dengan tujuan menarik investor masuk melalui relaksasi perizinan dan regulasi investasi (Fitriadi et.al, 2017). Prioritas pemerintah berlanjut pada periode kedua pemerintahan Presiden Joko Widodo dengan disahkan Omnibus Law Cipta Kerja pada bulan Oktober 2020 yang pada pokoknya menurut hemat penulis juga bertujuan untuk menstimulus ekonomi dan menarik investor guna menciptakan lapangan pekerjaan.

Namun upaya untuk menarik investor sesungguhnya tidak cukup hanya dengan mempermudah perizinan memberikan insentif pajak dan hal - hal lain yang terkait kebijakan ekonomi lainnya tanpa memperhatikan aspek penegakan hukum di Indonesia. Tentunya agar investor dapat menginvestasikan dana di suatu negara dibutuhkan trust atau kepercayaan akan penegakan hukum dan tentunya institusi peradilan yang accessible, efektif, efisien dan berbiaya murah atau disebut juga sebagai peradilan yang menganut asas contante justitie. Hal ini mutlak dibutuhkan karena bukan tidak 
mungkin investor yang masuk ke Indonesia di kemudian hari mengalami persoalan hukum terkait investasinya, tentunya mereka mengingkan penyelesaian sengketa yang efektif, efisien dan berbiaya murah.

Asas contante justitie atau biasa juga disebut sebagai asas peradilan sederhana, cepat dan biaya ringan sejatinya telah dianut oleh Indonesia sebagaimana termaktub secara jelas pada Pasal 2 ayat (4) Undang-Undang No. 48 Tahun 2009 tentang Kekuasaan Kehakiman. Namun tolak ukur prinsip hukum ini belum jelas sehingga menyebabkan inkonsistensi implementasi dalam proses peradilan (Hamzah, 2015).

Lilik Mulyadi memberikan kriteria terkait asas peradilan sederhana cepat dan biaya ringan, yakni ketika praktik peradilan memiliki pembatasan waktu penanganan perkara baik perkara pidana, maupun perdata di Pengadilan Tingkat Pertama dan Pengadilan Tingkat Banding (Mulyadi, 2007).

Mahkamah Agung sejatinya telah menerbitkan Surat Edaran Mahkamah Agung (SEMA) Nomor 2 Tahun 2014 tentang Penyelesaian Perkara di Pengadilan Tingkat Pertama dan Tingkat Banding Pada 4 (Empat) Lingkungan Peradilan yang menginstruksikan pengadilan untuk dapat menyelesaikan perkara pada tingkat pertama paling lambat 5 (lima) bulan dan pada tingkat banding paling lambat 3 (tiga) bulan. Namun dalam tataran praktik SEMA tersebut dapat dikatakan belum dapat terlaksana dengan baik.
Satu contoh dapat terlihat pada penyelesaian perkara gugatan wanprestasi oleh PT. Clemont Finance Indonesia yang membutuhkan waktu lebih dari 18 bulan pada tingkat pertama, belum lagi jika terjadi upaya hukum atas putusan pengadilan tingkat pertama tentunya akan memakan waktu bertahun-tahun hingga putusan tersebut berkekuatan hukum tetap dan dapat dieksekusi (Rivki, 2019).

Selain dengan menerbitkan SEMA yang membatasi jangka waktu maksimal penyelesaian perkara, Mahkamah Agung selaku stakeholder utama yang bertanggungjawab dalam pelaksanaan peradilan juga berupaya melakukan beberapa terobosan lain guna mewujudkan asas contante justitie pada peradilan di Indonesia. Salah satunya adalah dengan melakukan elektronisasi terhadap peradilan atau yang biasa dikenal dengan e-court.

Dengan adanya e-court beserta fiturfiturnya termasuk di dalamnya e-litigation yang menjadi pokok bahasan pada penelitian ini diharapkan dapat membawa efisiensi dalam proses peradilan di Indonesia. E-court jika diterapkan dengan efektif dapat menghemat waktu, biaya, dan tenaga para pihak dan advokat yang kerap antri cukup lama saat harus bersidang ke pengadilan (Elnizar, 2019).

Pada akhirnya, asas contante justitie sangat diharapkan dapat terwujud pada penyelesaian perkara perdata di pengadilan dikarenakan sifatnya yang terkait erat dengan investasi $\mathrm{Hal}$ ini menjadi wajar mengingat investasi merupakan hal yang dirangkai dengan 
Zil Aidi: E-Litigation Sebagai Sarana Mewujudkan Asas Contante Justitie Pada Peradilan...

suatu perjanjian keperdataan.

Sebagaimana yang sudah dipahami secara umum tentunya jika ada hak-hak keperdataan materil yang terlanggar maka hukum acara perdata adalah suatu tools untuk menegakkan hukum tersebut. Tentunya yang dibutuhkan adalah hukum acara perdata yang memenuhi asas contante justitie dan bisa memberikan kenyamanan bagi investor untuk berinvestasi di Indonesia.

\section{Tinjauan Umum E-Court}

Dunia telah memasuki sebuah era baru bernama revolusi industri 4.0. Revolusi industri 4.0 merupakan suatu peristilahan yang berasal dari Jerman saat pemerintah Jerman membentuk tim kerja industri 4.0 yang diketuai oleh Siegfried Dais (Robert Bosch GmBH) dan Henning Kagermann (German Academy of Science Engineering). Adapun tugas dari tim ini adalah untuk mempromosikan komputerisasi, digitalisasi, dan otomasi di sektor manufaktur (Germany Platform Industrie 4.0, 2020). Istilah Industri 4.0 sendiri pada mulanya merujuk pada suatu jaringan cerdas antar mesin dalam suatu sistem produksi dengan bantuan teknologi informasi dan komunikasi. Dewasa ini pengertian industri 4.0 telah mengalami ekstensifikasi makna, tidak hanya secara terbatas mengacu pada konektivitas mesin dan sistem produksi, tetapi juga merujuk pada suatu sistem terpadu antara teknologi maju dengan dunia fisik dan digital yang dengannya memungkinkan munculnya suatu sistem kerja yang inovatif, revolusioner, dan lebih efisien (Wibowo, 2020).
Revolusi industri 4.0 adalah didorong oleh kebutuhan masyarakat akan efisiensi dan kemudahan dalam segala aspek kehidupannya. Salah satu aspek penting yang dikehendaki oleh masyarakat efisiensi dan kemudahannya adalah terkait dengan pelayanan publik, terkhusunya di sektor yudisial atau peradilan. Selama ini sudah menjadi semacam stereotype masyarakat bahwa pelayanan publik di pengadilan berbelit-belit, tidak efisien serta berbiaya mahal. Persepsi publik terhadap pelayanan publik di pengadilan ini didukung juga oleh hasil riset Masyarakat Pemantau Peradilan Indonesia (MaPPI) yang pada pokoknya menyatakan pengadilan di dalam pelayanannya terhadap publik memiliki kelemahan sebagai berikut (Hidayat, 2016):

a Ketepatan waktu dan jadwal persidangan;

Masih ditemui adanya pengadilan yang tidak memiliki jadwal sidang sebanyak 21.43\%. Sedangkan pengadilan yang tidak memperbaharui jadwal sidang sebesar $8.93 \%$

b Ketersediaan layanan informasi pengadilan yang tidak merata;

Praktiknya, terjadi perbedaan perlakuan yang diberikan oleh petugas pengadilan terhadap pemohon informasi. Masyarakat awam hukum cenderung mendapatkan informasi lebih terbatas dibanding pemohon informasi tertentu. 
c Masih maraknya pungutan liar pada proses administrasi perkara di pengadilan.

Masih terdapat pengadilan memungut biaya layanan informasi yang bersifat umum, tentunya kondisi ini dapat mengakibatkan tingkat kepuasan pengguna pengadilan menurun terhadap layanan dari pengadilan tersebut.

Selain itu, problematika juga kerap terjadi pada manajemen administrasi di pengadilan. Pada manajemen administrasi di pengadilan, identik dengan tatap muka antara pencari keadilan dengan staf administrasi pada pelayanan satu pintu pengadilan, sehingga bagi masyarakat yang memiliki domisili yang jauh dari pengadilan harus membawa berkas yang banyak ditambah dengan adanya potensi antrian yang menumpuk di pengadilan (Susanto et.al, 2020). Kondisi tersebut jika terus dibiarkan tentu akan menjadi penghalang bagi Mahkamah Agung sebagai lembaga tertinggi pengampu kekuasaan kehakiman untuk mewujudkan asas contante justitie atau asas peradilan sederhana, cepat dan biaya ringan sebagaimana diamanatkan dalam UndangUndang No. 48 Tahun 2009 tentang Kekuasaan Kehakiman.

Salah satu upaya yang dilakukan Mahkamah Agung untuk memperbaiki pelayanan di pengadilan adalah dengan meluncurkan sistem e-court atau administrasi perkara dan persidangan secara elektronik. E-court pertama kali diluncurkan pada tahun 2018 dengan terbitnya PERMA Nomor 3 Tahun 2018 tentang Administrasi Perkara di Pengadilan Secara Elektronik. Kemudian, pada bulan Agustus 2019, Mahkamah Agung menerbitkan PERMA Nomor 1 Tahun 2019 tentang Administrasi Perkara dan Persidangan di Pengadilan Secara Elektronik. PERMA ini merupakan pengganti sekaligus penyempurna dari PERMA Nomor 3 Tahun 2018 tentang Administrasi Perkara di Pengadilan Secara Elektronik.

Kedua PERMA di atas merupakan salah satu terbosan besar dan inovatif yang mampu menyejajarkan peradilan di Indonesia dengan dengan Supreme Court Amerika Serikat, Supreme Court Inggris, dan Supreme Court Singapura yang terlebih dahulu menerapkan Electronic Filing System (Achmad, 2019).

Dari sisi terminologis e-court adalah sebuah instrumen pengadilan sebagai bentuk pelayanan terhadap masyarakat dalam hal pendaftaran perkara secara online (e-filing), taksiran panjar biaya secara elektronik (e-SKUM), pembayaran panjar biaya secara online (e-payment), pemanggilan pihak secara online (esummons) dan persidangan secara online (e-litigation) (Mahkamah Agung, 2019a). Penerapan peradilan secara elektronik sangat membantu terwujudnya visi Mahkamah Agung menjadi Badan Peradilan Indonesia Yang Agung, salah satunya yaknu mewujudkan Badan Peradilan Modern dengan berbasis Teknologi Informasi Terpadu (Djatmiko, 2019). Adapun pengadilan yang menyediakan e-court adalah Pengadilan Negeri, Pengadilan Agama/Mahkamah 
Zil Aidi: E-Litigation Sebagai Sarana Mewujudkan Asas Contante Justitie Pada Peradilan...

Syariah, Pengadilan Militer dan Pengadilan Tata Usaha Negara.

Selanjutnya, e-litigation atau persidangan secara elektronik merupakan fitur terbaru dari e-court yang mana baru keberlakuannya adalah melalui PERMA Nomor 1 Tahun 2019 tentang Administrasi Perkara dan Persidangan di Pengadilan Secara Elektronik, dimana pada PERMA Nomor 3 Tahun 2018 tentang Administrasi Perkara di Pengadilan Secara Elektronik fitur ini belum tersedia. Fitur ini merupakan salah satu kebaruan yang muncul dengan lahirnya PERMA Nomor 1 Tahun 2019 tentang Administrasi Perkara dan Persidangan di Pengadilan Secara Elektronik, kebaruan lain adalah dimungkinkannya pihak selain advokat untuk menggunakan e-court yang mana pada PERMA Nomor 3 Tahun 2018 tentang Administrasi Perkara di Pengadilan Secara Elektronik hanya advokat saja yang bisa mempergunakan ecourt. Begitu juga pada e-litigation yang dapat digunakan secara luas baik oleh jaksa, biro hukum, perorangan atau lembaga maupun kuasa insidentil (Syahr, 2020).

Secara garis besar mekanisme administrasi perkara dan persidangan di pengadilan secara elektronik atau $e$-court, adalah terdiri atas fitur - fitur sebagai berikut (Mahkamah Agung, 2019a):

a Pendaftaran Perkara Online (e-filing)

Pendaftaran Perkara Online dalam aplikasi e-court untuk saat ini baru dibuka jenis pendaftaran untuk perkara gugatan, bantahan, gugatan sederhana, dan permohonan. Pada saat dasar pengaturan e-court masih pada PERMA Nomor 3 Tahun 2018 tentang Administrasi Perkara di Pengadilan Secara Elektronik, hanya advokat saja yang dapat menggunakan sistem e-court. Namun, setelah diterbitkannya PERMA Nomor 1 Tahun 2019 tentang Administrasi Perkara dan Persidangan di Pengadilan Secara Elektronik dimungkinkan adanya pengguna ecourt selain dari advokat. Saat ini terdapat dua jenis pengguna e-court, pertama pengguna terdaftar yakni advokat yang telah terdaftar dan selanjutnya adalah pengguna lain atau pengguna insidentil yakni selain advokat. Sebelum melakukan pendaftaran perkara bagi advokat, syarat wajib yang harus dilakukan adalah harus memiliki akun pada aplikasi e-court. Untuk melakukan pendaftaran melalui e-court yang dilakukan pertama kali adalah membuka website e-court Mahkamah Agung di https://ecourt.mahkamahagung.go.id dan menekan tombol Register Pengguna Terdaftar. Sedangkan untuk pengguna lain atau insidentil, maka terlebih dahulu harus melakukan pendaftaran secara manual ke pengadilan untuk kemudian mendapatkan account agar dapat melakukan pendaftaran perkara secara elektronik. Barulah setelah akun ecourt dimiliki maka dapat dilakukan pendaftaran perkara melalui website 
e-court Mahkamah Agung di https://ecourt.mahkamahagung.go.id dan menekan tombol Login dengan memasukkan username dan password yang telah didapat dari pengadilan. Adapun akun bagi pengguna lain atau insidentil adalah bersifat temporer, dalam artian hanya berlaku untuk pendaftaran satu nomor perkara saja, berbeda dengan akun bagi pengguna advokat yang berlaku untuk perkaraperkara seterusnya.

b Taksiran Panjar Biaya Secara Elektronik (e-SKUM), Pembayaran Panjar Biaya Secara Online (ePayment)

Dalam proses pendaftaran perkara, pengguna terdaftar akan langsung mendapatkan Surat Kuasa Untuk Membayar (SKUM) yang digenerate secara elektronik oleh aplikasi e-court. Dalam proses generate tersebut sudah akan dihitung berdasarkan Komponen Biaya apa saja yang telah ditetapkan dan dikonfigurasi oleh Pengadilan, dan Besaran Biaya Radius yang juga ditetapkan oleh Ketua Pengadilan sehingga perhitungan taksiran biaya panjar sudah diperhitungkan sedemikian rupa dan menghasilkan elektronik SKUM atau e-SKUM. Pengguna Terdaftar setelah mendapatkan Taksiran Panjar atau eSKUM akan mendapatkan Nomor Pembayaran (Virtual Account) sebagai rekening virtual untuk pembayaran Biaya Panjar Perkara.

c Pemanggilan Pihak Secara Online (esummons)
Pemanggilan yang pendaftarannya dilakukan dengan menggunakan ecourt, maka pemanggilan kepada Pengguna Terdaftar dilakukan dilakukan secara elektronik yang dikirimkan ke alamat domisili elektronik pengguna terdaftar. Akan tetapi untuk pihak tergugat untuk pemanggilan pertama dilakukan dengan manual dan pada saat tergugat hadir pada persidangan yang pertama akan diminta persetujuan apakah setuju di panggilan secara elektronik atau tidak, jika setuju maka akan pihak tergugat akan dipanggil secara elektronik sesuai dengan domisili elektronik yang diberikan dan apabila tidak setuju pemanggilan dilakukan secara manual seperti biasa.

d Persidangan Secara Online (elitigation)

Aplikasi e-court juga mendukung dalam hal persidangan secara elektronik sehingga dapat dilakukan pengiriman dokumen persidangan seperti Replik, Duplik, Kesimpulan dan atau Jawaban secara elektronik yang dapat diakses oleh Pengadilan dan para pihak. Selain itu, e-litigation juga dimungkinkan dalam hal pemeriksaan saksi atau ahli secara elektronik dengan menggunakan media komunikasi visual, begitu juga dengan pembacaan putusan yang mana dapat dilakukan secara elektronik.

\section{Tinjauan E-Litigation di Indonesia}


Zil Aidi: E-Litigation Sebagai Sarana Mewujudkan Asas Contante Justitie Pada Peradilan...

E-Court mulai berlaku di Indonesia pada tanggal 4 April 2018 atau saat diundangkannya PERMA No. 3 Tahun 2018 tentang Administrasi Perkara di Pengadilan Secara Elektronik oleh Mahkamah Agung. Adapun tujuan dari dihadirkannya e-court adalah sebagai suatu bentuk upaya dari Mahkamah Agung untuk mewujudkan peradilan yang accessible, efektif, efisien dan berbiaya murah atau disebut juga sebagai peradilan yang menganut asas contante justitie sebagaimana diamanatkan oleh Pasal 2 ayat (4) Undang-Undang No. 48 Tahun 2009 tentang Kekuasaan Kehakiman.

Selanjutnya pada tanggal 8 Agustus 2019, PERMA No. 1 Tahun 2019 tentang Administrasi Perkara dan Persidangan di Pengadilan Secara Elektronik diundangkan sebagai pengganti dari aturan sebelumnya yakni PERMA No. 3 Tahun 2018. PERMA Nomor 1 Tahun 2019 ini menyempurnakan PERMA Nomor 3 Tahun 2018 sehingga saat ini tidak hanya pendaftaran perkara saja yang dapat dilaksanakan online atau dikenal dengan sebutan e-court, akan tetapi persidangan juga dapat dilakukan secara elektronik yaitu e-litigation (Retnaningsih et.al, 2020). Pada PERMA No. 3 Tahun 2018 fitur yang dimiliki oleh e-court adalah pendaftaran perkara secara online (e-filing), taksiran panjar biaya secara elektronik (e-SKUM), pembayaran panjar biaya secara online (e-payment) dan pemanggilan pihak secara online (esummons). Fitur ini kemudian bertambah dengan adanya e-litigation atau persidangan secara elektronik yang diatur oleh PERMA No. 1 Tahun 2019.

Definisi yuridis dari e-litigation dapat ditemukan pada Pasal 1 angka (7) PERMA No. 1 Tahun 2019 yang mendefinisikan e-litigation atau persidangan secara elektronik sebagai serangkaian proses memeriksa dan mengadili perkara oleh pengadilan yang dilaksanakan dengan dukungan teknologi informasi dan komunikasi.

Ruang lingkup dari e-litigation dapat ditemukan pada Pasal 4 PERMA No. 1 Tahun 2019 yang pada pokoknya menyatakan bahwa e-litigation berlaku pada proses persidangan dengan acara penyampaian gugatan / permohonan / bantahan / perlawanan / intervensi beserta perubahannya, jawaban, replik, duplik, pembuktian, kesimpulan dan pengucapan putusan atau penetapan.

Selanjutnya, pengaturan lebih detail mengenai e-litigation dapat ditemukan pada BAB V PERMA No. 1 Tahun 2019 yang secara umum mengatur mengenai hal-hal sebagai berikut:

a Pasal 19 yang pada pokoknya menyatakan Hakim dapat memberitahukan kepada para pihak terkait hak dan kewajiban para pihak dalam melaksanakan persidangan secara elektronik demi kelancaran persidangan secara elektronik. Dimana makna Pasal 19 ini memiliki makna yang sama dengan Pasal 132 HIR terkait peranan Hakim dalam menunjukkan upaya hukum dan alatalat bukti kepada para pihak yang 
dipandang perlu guna kelancaran persidangan.

b Pasal 20 pada pokoknya menyatakan bahwa persidangan secara elektronik hanya dapat dilaksanakan jika ada persetujuan dari penggugat maupun tergugat.

c Pasal 21 mengatur terkait peranan Hakim dalam menetapkan jadwal persidangan elektronik untuk acara penyampaian jawaban, replik dan duplik hingga penyampaian putusan. Adapun persidangan secara elektronik dilaksanakan pada Sistem Informasi Pengadilan.

d Pasal 22 mengatur terkait teknis penyampaian jawaban, replik, duplik dan kesimpulan yang mana paling lambat secara elektronik pada hari dan jam sidang sesuai dengan jadwal yang ditetapkan untuk kemudian diteruskan oleh Hakim kepada pihak lain. Apabila tidak menyampaikan dokumen elektronik terkait hal - hal di atas pada hari dan jam persidangan yang terjadwal, maka para pihak dianggap tidak menggunakan haknya untuk mengajukan dokumen tersebut. Dokumen berupa Jawaban harus disertai dengan bukti berupa surat yang sudah dalam bentuk elektronik. Keseluruhan tahapan ini dicatat oleh panitera dalam Berita Acara Sidang Elektronik. SKMA

e Pasal 23 memungkinkan adanya permohonan intervensi oleh pihak ketiga terhadap perkara yang sedang disidangkan secara elektronik. Namun, pihak ketiga tersebut wajib mengikuti proses pemeriksaan perkara secara elektronik tersebut. Dalam hal Pihak Ketiga tidak setuju mengikuti proses persidangan secara elektronik maka permohonan intervensinya dinyatakan tidak dapat diterima.

f Pasal 24 mengatur terkait pelaksanaan pemeriksaan alat bukti saksi dan atau ahli dapat dilakukan secara jarak jauh melalui media komunikasi audio visual menggunakan fasilitas yang disediakan oleh pengadilan.

g Pasal 25 mengatur mengenai pelaksanaan pembuktian di pengadilan yang menggunakan hukum acara perdata sebagaimana biasanya.

h Pasal 26 adalah terkait dengan pembacaan putusan atau penetapan secara elektronik oleh Hakim. Pembacaan atau pengucapan putusan secara elektronik adalah dengan disampaikannya Salinan putusan atau penetapan secara elektronik kepada para pihak. Penyampaian dengan acara elektronik tersebut di secara hukum dianggap telah dihadiri oleh para pihak dan dilakukan di sidang terbuka untuk umum.

i Pasal 27 menyatakan bahwa persidangan secara elektronik yang dilaksanakan dalam Sistem Informasi Pengadilan pada jaringan internet publik secara hukum telah memenuhi ketentuan sidang terbuka untuk umum sesuai dengan ketentuan perundangundangan.

j Pasal 28 mengatur mengenai penggantian atau pencabutan kuasa hukum atau Advokat ditengah persidangan yang mana mewajibkan prinsipal untuk melaporakannya 
Zil Aidi: E-Litigation Sebagai Sarana Mewujudkan Asas Contante Justitie Pada Peradilan...

terlebih dahulu ke kepaniteraan. Advokat atau kuasa hukum pengganti harus merupakan pengguna terdaftar atau pengguna lain dari e-court.

\section{Penerapan dan Hambatan E- Litigation di Pengadilan Negeri Yogyakarta}

Pengadilan Negeri (PN) Yogyakarta Kelas IA berlokasi di Jalan Kapas No. 10, Kota Yogyakarta, Daerah Istimewa Yogyakarta. PN Yogyakarta sudah menyediakan layanan e-court sejak akhir tahun 2018.

Berdasarkan data Mahkamah Agung yang dapat diakses pada website e-court sampai dengan tanggal 17 Oktober 2020 di PN Yogyakarta telah terdapat 435 pendaftaran e-court dengan 432 perkara hingga mendapatkan nomor perkara. Adapun perincian 432 perkara itu terdiri atas 198 perkara gugatan, 12 perkara gugatan sederhana, perkara bantahan sejumlah 7 dan perkara permohonan sejumlah 215 (Mahkamah Agung, 2020b).

Dari data tersebut di atas dapat disimpulkan bahwasanya pengguna ecourt dalam hal ini fitur e-filing atau pendaftaran perkara secara online telah berjalan di PN Yogyakarta. Hal ini senada dengan hasil wawancara dengan Bapak Dr. Fahmiron, S.H., M.Hum selaku Wakil Ketua PN Yogyakarta yang menyampaikan bahwasanya untuk pendaftaran perkara secara elektronik atau e-filing dapat dikatakan sudah berjalan dengan baik dimana hal ini terlihat dengan pengguna peradilan perdata yang berasal dari kalangan Advokat telah menggunakan e-filing untuk pendaftaran perkaranya. Begitu juga dengan fitur taksiran panjar biaya secara elektronik (eSKUM) dan pembayaran panjar biaya secara online (e-payment) yang telah banyak dimanfaatkan oleh pengguna peradilan yang berasal dari kalangan Advokat (Fahmiron, 2020). Namun untuk pengguna peradilan yang berasal dari perseorangan atau kalangan lainnya yang bukan advokat memang masih ada yang belum menggunakan e-court dalam pendaftaran perkara. PN Yogyakarta sendiri tidak memiliki kebijakan yang bersifat memaksa kepada pengguna peradilan untuk menggunakan e-court dalam pendaftaran perkara, namun PN Yogyakarta berupaya untuk mengedukasi dan mensosialisasikan kemudahan dan efisiensi yang akan didapatkan jika menggunakan e-court kepada pengguna peradilan. Sosialisasi dan edukasi ini bisa diperoleh dengan mendatangi pojok pelayanan e-court di PN Yogyakarta.

Sedangkan untuk fitur e-litigation yang menjadi fokus bahasan pada penelitian ini, di PN Yogyakarta dapat dikatakan belum berjalan dengan optimal dan efektif. Sebenarnya dari segi infrastruktur PN Yogyakarta bersama dengan 381 pengadilan negeri lain di seluruh Indonesia sudah siap untuk mengimplementasikan e-litigation (Mahkamah Agung, 2020a). Hal ini dapat dicermati dengan telah tersedianya infrastruktur berupa sistem informasi yang menjadi sarana untuk menyerahkan dokumen secara elektronik hingga ketersediaan fasilitas media komunikasi 
audio visual untuk menopang pelaksanaan pemeriksaan saksi atau ahli secara elektronik.

Namun ketersediaan fasilitas tersebut belum diimbangi dengan minat dari pengguna peradilan untuk menggunakan e-litigation. E-litigation yang berjalan di PN Yogyakarta barulah sebatas penyampaian dokumen seperti gugatan, jawaban, replik, duplik dan kesimpulan secara elektronik dan pembacaan putusan secara elektronik melalui sistem e-court sedangkan untuk fasilitas lain seperti pemeriksaan saksi atau ahli belum ada yang terlaksana secara elektronik (Fahmiron, 2020). Lebih lanjut, pemanfaatan praktik e-litigation di $\mathrm{PN}$ Yogyakarta sebagian besar terjadi perkara-perkara perceraian yang umumnya tidak dihadiri oleh tergugat atau dalam artian di putus verstek. Dalam perkara seperti ini maka proses pengiriman dokumen, pemeriksaan alat bukti surat atau tulisan, hingga putusan dilaksanakan secara elektronik. Alasan yang mendasari dimungkinkannya elitigation pada perkara perceraian yang diputus verstek adalah dikarenakan hanya ada satu pihak saja yang hadir ke persidangan sehingga cukup dengan persetujuan satu pihak saja maka elitigation bisa dilakukan.

Sebaliknya, pada perkara yang para pihak baik itu penggugat dan tergugat hadir masih minim jumlahnya yang menggunakan e-litigation. Hal ini dikarenakan memang e-litigation hanya bisa dilaksanakan adanya consent atau persetujuan dari para pihak untuk bersidang secara elektronik. Tanpa adanya persetujuan dari pihak tentu penyampaian jawaban, replik, duplik, pemeriksaan saksi atau ahli secara elektronik hingga pembacaan putusan secara elektronik sebagai bagian dari elitigation tentu tidak dapat dilaksanakan (Aidi, 2020).

Setidaknya ada dua faktor yang menyebabkan masih belum optimalnya pemanfaatan e-litigation di PN Yogyakarta (Fahmiron, 2020). Faktor pertama datang dari sisi pengguna peradilan yang masih memiliki pemahaman dan literasi yang kurang memadai terkait pemanfaatan teknologi. Hal ini berakibat pada adanya kekhawatiran mereka jika menyampaikan dokumen seperti jawaban, replik dan duplik serta mengajukan alat bukti secara elektronik melalui sistem e-court maka tidak akan tersampaikan dengan baik kepada pengadilan maupun pihak lawan. Kekhawatiran ini sebenarnya tidak perlu ada karena sistem e-court dari Mahkamah Agung sudah baik dan justru ketika dikirimkan via sistem e-court dokumen hukum tersebut akan lebih aman karena otomatis akan terarsip pada sistem. Tentunya kondisi ini menjadi tugas bagi Mahkamah Agung secara umum dan PN Yogyakarta secara khusus untuk lebih meningkatkan sosialisasi dan edukasi terkait kemudahan dan efisiensi yang akan didapatkan dari penggunaan elitigation kepada masyarakat pengguna peradilan.

Faktor kedua yang kemudian menjadi penghambat terimplementasikannya e- 
litigation datang dari regulasi e-litigation itu sendiri. Pertama terkait dengan penyampaian dokumen dan alat bukti tertulis secara elektronik. E-litigation telah memfasilitasi penyampaian gugatan, jawaban, replik, duplik, kesimpulan serta pengajuan alat bukti secara elektronik akan tetapi tetap ada kewajiban bagi para pihak untuk datang ke persidangan untuk guna memverifikasi keaslian dokumen yang sebelumnya sudah diserahkan pada sistem e-court. Aturan ini sebagaimana tercantum dalam Surat Keputusan Ketua Mahkamah Agung No. 129/KMA/SK/VIII/2019 tentang Petunjuk Teknis Administrasi Perkara dan Persidangan di Pengadilan Secara Elektronik. Tentunya masyarakat pengguna peradilan akan berpikir dua kali untuk menyerahkan dokumen hukum dan alat bukti secara elektronik karena tidak lantas menghilangkan kewajiban bagi mereka untuk datang ke pengadilan untuk memverifikasi dokumen tersebut (Fahmiron, 2020).

Kedua adalah terkait dengan pemeriksaan saksi atau ahli secara elektronik yang mana dimungkinkan melalui media komunikasi audio visual dalam hal saksi atau ahli tersebut tidak dapat hadir langsung di persidangan. Pengguna peradilan pada akhirnya enggan menggunakan fasilitas ini karena bagaimanapun juga saksi atau ahli yang mereka ajukan tetap harus datang ke PN terdekat dimana mereka berada untuk melaksanakan persidangan menggunakan fasilitas media komunikasi audio visual yang terdapat pada PN tersebut. Sebagai contoh, seorang saksi yang berdomisili di Kabupaten Bantul, kemudian akan bersaksi di PN Yogyakarta maka orang tersebut harus datang ke PN Bantul untuk kemudian bersaksi menggunakan fasilitas media komunikasi audio visual seperti teleconference yang terdapat pada PN Bantul (Fahmiron, 2020). Dalam artian saksi tersebut tidak dimungkinkan untuk bersaksi dari kediamannya akan tetapi harus mencari PN terdekat. Hal ini sebagaimana juga diatur pada Surat Keputusan Ketua Mahkamah Agung No. 129/KMA/SK/VIII/2019 tentang Petunjuk Teknis Administrasi Perkara dan Persidangan di Pengadilan Secara Elektronik. Pada akhirnya saksi atau ahli memilih untuk langsung datang saja ke PN yang menangani perkara dan kemudian memberikan kesaksian atau keterangan secara langsung karena pada akhirnya tetap harus datang ke PN.

Dalam menyikapi hambatanhambatan yang berasal dari regulasi tentunya dibutuhkan inisiatif dari Mahkamah Agung untuk mengevaluasi pelaksanaan e-litigation terkhususnya terkait dengan verifikasi dokumen dan alat bukti tertulis maupun pemeriksaan saksi atau ahli secara elektronik. Hal ini penting untuk dilakukan karena sebagaimana sudah disampaikan kedua fasilitas e-litigation tersebut pada akhirnya kurang mendapatkan respon yang baik dari masyarakat karena pada akhirnya mekanismenya tetap mewajibkan pengguna peradilan untuk hadir ke PN. Dimana seharusnya ketika berbicara mengenai elektronisasi 
peradilan berarti kita berbicara mengenai pengurangan intensitas untuk hadir langsung ke pengadilan. Terlebih pada situasi pandemik COVID-19 yang tengah berlangsung saat ini memang menghendaki kita untuk menghindari berkerumum atau berkumpulnya banyak orang dalam satu tempat, tak terkecuali di PN.

\section{Penerapan dan Hambatan E- Litigation di Pengadilan Negeri Marabahan}

Pengadilan Negeri (PN) Marabahan adalah pengadilan negeri Kelas II yang berlokasi Jalan Jenderal Sudirman RT. 12 Kel. Ulu Benteng Kabupaten Barito Kuala, Kalimantan Selatan. PN Marabahan telah menyediakan layanan $e$ court secara efektif sejak awal tahun 2019

Pemilihan PN Marabahan sebagai salah satu objek penelitian didasari oleh alasan bahwasanya penulis ingin melihat penerapan e-litigation tidak hanya pada pengadilan yang berada di kota besar saja melainkan ingin melihat sejauh apa elitigation sudah diterapkan di daerah.

Adapun, statistik pengguna e-court di PN Marabahan sampai dengan tanggal 17 Oktober 2020 adalah sejumlah 15 pendaftaran e-court dengan 15 perkara hingga mendapatkan nomor perkara. Adapun perincian 15 perkara itu terdiri atas 8 perkara gugatan, 3 perkara gugatan sederhana, dan permohonan sejumlah 4 (Mahkamah Agung, 2020c).

Berdasarkan hasil wawancara dengan Novitasari Tri Haryanti, S.H. selaku Hakim PN Marabahan didapatkan fakta bahwasanya e-court sudah terimplementasi dengan baik di PN Marabahan. Dalam hal ini adalah fitur ecourt yang terkait dengan pendaftaran perkara secara online (e-filing), taksiran panjar biaya secara elektronik (e-SKUM) dan pembayaran panjar biaya secara online (e-payment). Hampir semua pendaftaran perkara perdata di PN Marabahan telah menggunakan e-court dikarenakan masyarakat pengguna peradilan telah merasakan kemudahan yang didapatkan dengan menggunakan ecourt (Haryanti, 2020).

Namun untuk fitur e-litigation belum dapat terimplementasikan dengan optimal di PN Marabahan. Praktik e-litigation yang terjadi barulah sebatas penyerahan dokumen gugatan melalui sistem e-court yang mana biasanya memang dilakukan bersamaan dengan pendaftaran gugatan melalui fitur e-filing. Adapun faktor yang menghambat terimplementasinya elitigation dengan baik di PN Marabahan hampir sama dengan yang terjadi di PN Yogyakarta yakni terkait masih belum memadainya tingkat literasi dan pemahaman masyarakat pengguna peradilan terkait penggunaan teknologi informasi.

Kondisi ini berdampak pada adanya keengganan mereka untuk melaksanakan persidangan secara elektronik atau elitigation karena khawatir dokumen atau hal-hal lain yang terkait dengan persidangan tidak dapat mereka terima dengan baik karena dilakukan secara online pada sistem e-court. Tentunya tanpa adanya persetujuan dari para pihak 
Zil Aidi: E-Litigation Sebagai Sarana Mewujudkan Asas Contante Justitie Pada Peradilan...

dalam perkara maka e-litigation tidak akan bisa dilaksanakan. Kondisi ini sekali lagi membutuhkan peranan dari Mahkamah Agung dan tentunya PN Marabahan untuk lebih meningkatkan sosialisasi dan edukasi kepada masyarakat agar mereka lebih memahami e-litigation.

Selain itu pada PN Marabahan terdapat hambatan yang terkait dengan infrastuktur yakni akses internet yang stabil (Haryanti, 2020). Ketiadaan akses internet yang stabil menyulitkan pihak PN Marabahan apabila nantinya ada pihak yang menggunakan e-litigation terkait pemeriksaan saksi atau ahli jarak jauh melalui sarana media komunikasi audio visual. Tentunya akan sulit berkomunikasi melalui media tersebut jika di lokasi tempat PN Marabahan berada memiliki akses internet yang kurang memadai. Terkait hal ini tentu Mahkamah Agung perlu berkoordinasi dan bekerjasama dengan perusahaan penyedia jasa internet agar setidaknya di sekitar lingkungan PN Marabahan internet dapat diakses dengan lebih baik dan stabil guna kepentingan elitigation.

\section{SIMPULAN}

Penerapan e-litigation di PN Yogyakarta dan PN Marabahan secara umum dapat dikatakan belum berjalan dengan optimal dan belum dapat berkontribusi maksimal dalam mewujudkan asas contante justitie. Pada PN Yogyakarta penggunaan e-litgation masih terbatas pada perkara perceraian yang diputus verstek dalam artian hanya satu pihak saja yang hadir. Adapun praktik e-litigation yang digunakan juga baru sebatas penyampaian dokumen seperti gugatan, jawaban, replik, duplik dan kesimpulan secara elektronik dan pembacaan putusan secara elektronik melalui sistem e-court sedangkan untuk fasilitas lain seperti pemeriksaan saksi atau ahli belum ada yang terlaksana secara elektronik. Sedangkan di PN Marabahan praktik e-litigation lebih terbatas lagi hanya pada penyerahan gugatan secara elektronik yang mana sebenarnya juga merupakan bagian dari fitur e-filing.

Faktor-faktor yang menyebabkan terhambatnya pelaksanaan e-litigation adalah pertama terkait dengan ketidaktahuan masyarakat pengguna peradilan terhadap keuntungan menggunakan fitur tersebut. Faktor lain adalah terkait dengan regulasi dari elitigation itu sendiri yang mana tetap mewajibkan para pihak untuk datang ke persidangan untuk memverifikasi dokumen maupun alat bukti tertulis yang sebenarnya sudah disubmit atau diserahkan di sistem e-court. Kondisi ini membuat akhirnya pengguna peradilan untuk tidak menggunakan e-litigation karena pada akhirnya tetap harus datang ke pengadilan. Begitu juga aturan mengenai pemeriksaan saksi atau ahli secara elektronik yang tetap mewajibkan saksi atau ahli tersebut memberikan kesaksian di pengadilan terdekat menggunakan fasilitas media komunikasi audio visual pengadilan tersebut. Pada akhirnya saksi atau ahli lebih memilih untuk memberikan kesaksian langsung ke PN yang menangani perkara karena 
akhirnya tetap harus datang ke PN. Selain itu juga terdapat hambatan terkait infrastruktur dalam hal ini akses sinyal internet yang kurang baik di daerah dimana PN Marabahan berlokasi yang menyulitkan untuk dilaksanakannya pemeriksaan saksi atau ahli secara elektronik.

Penulis menyarankan diperlukan adanya sosialisasi yang lebih masif baik dari Mahkamah Agung maupun PN terkait manfaat e-court terkhususnya elitigation kepada masyarakat, agar masyarakat semakin paham dan tertarik untuk menggunakan seluruh fitur dalam sistem e-court tersebut. Kesiapan infrastruktur dalam hal ini sinyal dan akses internet yang memadai juga perlu ditingkatkan guna memfasilitasi pemeriksaan saksi atau ahli secara online. Selain itu, diperlukan adanya evaluasi terkait pelaksanaan e-litigation yang telah berlangsung hampir 1 tahun ini oleh Mahkamah Agung khususnya terkait dengan regulasi yang kurang efektif dalam e-litigation.

\section{UCAPAN TERIMA KASIH}

Terima kasih yang sebesar-besarnya kepada semua pihak yang telah membantu kelancaran penulisan dan penelitian ini, terkhususnya kepada Bapak Dr. Fahmiron, S.H., M.Hum selaku Wakil Ketua PN Yogyakarta, dan juga Ibu Novitasari Tri Haryanti, S.H selaku Hakim PN Marabahan yang telah berkenan penulis wawancarai. Besar harapan kontribusi kecil ini dapat memberi kemanfaatan bagi upaya menciptakan proses peradilan khususnya pada perkara perdata yang lebih efektif dan efisien.

\section{DAFTAR PUSTAKA}

Achmad, Rafli Fadilah. (2019). "E-Court, Prospek Cemerlang Masa Depan Peradilan Indonesia", https://www.hukumonline.com/berit a/baca/lt5bd6d11999924/e-court-prospek-cemerlang-masa-depanperadilan-indonesia-oleh--raflifadilah-achmad/, diakses pada tanggal 10 Februari 2020.

Aidi, Zil. (2020). Implementasi E-Court Dalam Mewujudkan Penyelesaian Perkara Perdata Yang Efektif Dan Efisien, Jurnal Masalah-Masalah Hukum Fakultas Hukum Universitas Diponegoro, Vol. 49 No.1.

Andayani, Dwi. (2019). “MA Targetkan Seluruh Pengadilan Terapkan ELitigasi Pada 2020”, https://news.detik.com/berita/d4713073/ma-targetkan-seluruhpengadilan-terapkan-e-litigasi-pada2020 diakses pada 9 Februari 2020

Anggraeni, RR. Dewi. (2020). Wabah Pandemi COVID-19 Urgensi Pelaksanaan Sidang Secara Elektronik, Adalah: Buletin Hukum dan Keadilan, Fakultas Syariah dan Hukum UIN Syarif Hidayatullah Jakarta Vol. 4 No. 1.

Asikin, Zainal. (2004). Pengantar Metode Penelitian Hukum, Jakarta: Raja Grafindo Persada.

Basarah, Mochamad. (2007). Prospektif sistem Peradilan Di Indonesia, Jurnal Syiar Hukum, Universitas Islam Bandung, Vol. 9 No. 3.

Djatmiko, Hary. (2019). Implementasi Peradilan Elektronik (E-Court) 
Zil Aidi: E-Litigation Sebagai Sarana Mewujudkan Asas Contante Justitie Pada Peradilan...

Pasca Diundangkannya Perma Nomor 3 Tahun 2018 Tentang Administrasi Perkara di Pengadilan Secara Elektronik, Jurnal Legalita, Vol 01, No.1.

Elnizar, Norman Edwin. (2019). "Siapsiap Litigasi Lewat E-Court Dimulai Tahun Ini” https://www.hukumonline.com/berit a/baca/lt5d08d96f10a83/siap-siap-litigasi-lewat-e-court-dimulaitahun-ini/, diakses pada 9 Februari 2020

Fahmiron. (2020). Wawancara Hakim Pengadilan Negeri Yogyakarta pada tanggal 30 September 2020.

Fitriadi, Mireza, Prawira, Mohamad Yudha \& Aidi, Zil. (2017). Economic Policy Package: How Policy Delivery Affects Business Competition, Prosiding Seminar Internasional Academic Network on Competition Policy, 6 September 2017, Bali.

Germany Platform Industrie 4.0. (2019). "What Is Industrie 4.0", https://www.plattformi40.de/PI40/Navigation/EN/Industri e40/WhatIsIndustrie40/what-isindustrie40.html diakses pada tanggal 10 Februari 2020.

Hairi, Prianter Jaya. (2011). Antara Prinsip Peradilan Sederhana, Cepat dan Berbiaya Ringan dan Gagasan Pembatasan Perkara Kasasi, Jurnal Negara Hukum, Bidang Hukum, Pusat Penelitian, Badan Keahlian DPR RI, Vol. 2, No. 1.

Hamzah, Mohammad Amir. (2015). Tolak Ukur Prinsip Hukum Sederhana, Cepat dan Biaya Ringan pada Peradilan Perdata, Rechtldee Jurnal Hukum, Vol. 10 No.1.

Haryanti, Novitasari Tri. (2020). Wawancara Hakim Pengadilan Negeri Marabahan pada tanggal 15 Oktober 2020.

Hidayat, Rofiq. (2016). “MA Harus Fokus Pembenahan Pelayanan Publik di Pengadilan", https://www.hukumonline.com/berit a/baca/lt57b6fbf0efdf6/ma-harusfokus-pembenahan-pelayananpublik-di-pengadilan/, diakses pada tanggal 10 Februari 2020.

Lumbanraja, Anggita Doramia. (2020). Perkembangan Regulasi dan Pelaksanaan Persidangan Online di Indonesia dan Amerika Serikat Selama Pandemi Covid-19, Jurnal Crepido, Universitas Diponegoro, Vol. 2 No.1.

Mahkamah Agung. (2019a). Buku Panduan E-Court, Jakarta: Mahkamah Agung.

Mahkamah Agung. (2019b). "Laporan Pelaksanaan Kegiatan”, https://badilum.mahkamahagung.go. id/publik/laporan/laporantahunan.html, diakses pada 1 November 2020.

Mahkamah Agung. (2020a) "Peta ECourt Peradilan Umum. https://ecourt.mahkamahagung.go. id/mapecourt_umum diakses pada tanggal 17 Oktober 2020

Mahkamah Agung. (2020b). "Peta ECourt Peradilan Umum PN Yogyakarta". https://ecourt.mahkamahagung.go.id /mapecourt_umum diakses pada tanggal 17 Oktober 2020 
Mahkamah Agung. (2020c). "Peta ECourt Peradilan Umum PN Marabahan".

https://ecourt.mahkamahagung.go.id /mapecourt_umum pada tanggal 17 Oktober 2020

Mulyadi, Lilik. (2007). Hukum Acara Pidana: Normatif, Teoritis, Praktik dan Permasalahannya, Bandung: Alumni.

Retnaningsih, Sonyendah, Disriani Latifah Soroinda Nasution, Rouli Anita Velentina, Kelly Manthovani. (2020). Pelaksanaan E-Court Menurut Perma Nomor 3 Tahun 2018 Tentang Administrasi Perkara Di Pengadilan Secara Elektronik dan E-Litigation Menurut PERMA Nomor 1 Tahun 2019 Tentang Administrasi Perkara Dan persidangan Di Pengadilan Secara Elektronik (Studi Pengadilan Negeri Di Indonesia), Jurnal Hukum dan Pembangunan, Fakultas Hukum Universitas Indonesia, Vol. 50 No.1.

Rivki. (2017). "Hukum Penjajah Masih Eksis, Begini Lamanya Proses Gugat Perdata" https://news.detik.com/berita/d3721354/hukum-penjajah-masiheksis-begini-lamanya-proses-gugatperdata, diakses pada 9 Februari 2020.

Sari, Ni Putu Riyani Kartika. (2019). Eksistensi E-Court Untuk Mewujudkan Asas Sederhana,
Cepat dan Biaya Ringan Dalam Sistem Peradilan Perdata di Indonesia, Jurnal Yustitia Universitas Ngurah Rai Bali, Vol. 13 No.1.

Suparman, Eman. (2019). Verplichte Procureustelling Untuk Peradilan Yang Sederhana, Cepat dan Biaya Ringan, Jurnal Ilmu Hukum Veritas et Justitia, Fakultas Hukum Universitas Katolik Parahyangan, Vol.5 No. 1.

Susthira K, Melalusa. (2019). “Indeks Kepuasan Terhadap Lembaga Peradilan 76\%" https://mediaindonesia.com/read/det ail/238133-indeks-kepuasanterhadap-lembaga-peradilan-76 diakses pada 9 Februari 2020.

Syahr, Zulfia Hanum Alfi. (2020). Dinamika Digitalisasi Manajemen Layanan Pengadilan, Prosiding Seminar Nasional Pakar ke-3 Tahun 2020, 29 Februari 2020, Universitas Trisakti, Jakarta.

Wibowo, Budhi S. (2019). "Indonesia dan Industry $\quad 4.0 \quad$ (2)”, http://budhiwibowo.staff.ugm.ac.id/ 2019/01/08/i4-0-sejarah-kelahiranindustry-4-0/\#_ftnref4, diakses pada tanggal 10 Februari 2020. 